\title{
On the Effects of Technology Shocks Over Labor Input at Business-Cycle Frequencies: an Empirical Note
}

Matheus Albergaria de Magalhães* Paulo Picchetti**

\begin{abstract}
In the last years, there has been a heated debate over the empirical adequacy of Real-Business-Cycle (RBC) models (GALI, 1999; CHRISTIANO; EICHENBAUM; VIGFUSSON, 2003; FRANCIS; RAMEY, 2005). In this empirical note, we check the robustness of some of the main results obtained in this strand of the literature. Our contribution is twofold: first, we provide robust results by using different data sources; second, we show that the results related to labor input's dynamic pattern over business-cycle horizons are sensitive to the way labor input is modelled. The results obtained favor specifications where labor input is modelled as growth rates. These results may help distinguishing the most desirable empirical specifications to be employed over the debate in the future.
\end{abstract}

Keywords: Technology shocks. Business cycles. RBC models.

JEL Classification: E32; C32; C52.

\section{Introduction}

At least since Galî's empirical critique on RBC models through SVAR techniques (GALI, 1999), there has been a heated debate about the main effects of technology shocks over labor input at business-cycle frequencies. Francis and Ramey (2005) and Christiano, Eichenbaum and Vigfusson (2003) represent some of the main contributions to this debate. ${ }^{1}$

This debate's main concern has been labor input's dynamic pattern. Specifically, the response of labor input (usually measured as hours worked) to technology shocks may be helpful in distinguishing rival business-cycle theories. For instance, according to first-generation RBC models, hours worked should rise in response to a positive technology shock (if the substitution effect is larger than the income effect for the representative agent in one-agent models). However, with

\footnotetext{
* $\quad$ Especialista em Pesquisas Governamentais do Instituto Jones dos Santos Neves (IJSN). E-mail: matheus.ijsn@gmail.com

* * Professor de Economia e Pesquisador da Escola de Economia da Fundação Getúlio Vargas (EESP-FGV).E-mail: paulo.picchetti@fgv.br

For a survey on this debate, see Galí and Rabanal (2004).
} 
sluggish price adjustment, some firms in the economy may not be able to fully respond to a technology shock by adjusting its prices. In this case, firms will decrease labor and hours worked will fall. Thus, the empirical pattern of hours worked over time is seen as empirical evidence supporting either RBC or sticky-price business cycle models, basically. ${ }^{2}$

This note aims to make a contribution to the empirical debate cited above. By employing the SVAR methodology (BLANCHARD; QUAH, 1989) and the original datasets used by Galí (1999), Christiano, Eichenbaum and Vigfusson (2003) and Francis and Ramey (2005), we check the robustness of some of the main results obtained by these authors. ${ }^{3}$ Our results confirm Gali's and Francis and Ramey's main findings at the same time that they go against some of Christiano, Eichenbaum and Vigfusson's claims. Specifically, we obtain a result where SVAR specifications which model labor input as an I(0) process always violate SVAR's basic identification condition (where non-technology shocks do not affect productivity in the long run). Furthermore, technology shocks derived from such specifications cannot be characterized as exogenous, violating the Hall-Evans invariance property (to be defined below).

The paper is organized as follows: in the second section, we briefly review some of the main contributions to the debate cited above and its implications. In the third section, we describe the empirical framework used in the analysis, while in the fourth section we describe the variables employed in the analysis below. The fifth section contains the main empirical findings obtained in terms of SVAR estimations and Granger-causality tests. Finally, in the sixth section, we conclude the paper.

\section{Contributions to the Empirical Debate}

Employing the SVAR methodology, Gali (1999) tests the empirical adequacy of first-generation $\mathrm{RBC}$ models by estimating conditional correlations between productivity and labor input measures for G-7 countries. His model's identification condition is the following: technology shocks have a permanent effect over both variables in the estimated system (productivity and labor input), while non-technology shocks (which can be broadly seen as "demand" shocks) have a permanent

$2 \quad$ It is important to emphasize that there are RBC models where labor input can display a negative response to technology shocks (see Collard and Dellas, 2004, for instance). Still, the debate cited above concentrates on first-generation models, only.

3 After preparing the first draft of this paper, we noticed similar work by Whelan (2009), related to the technology-hours debate. According to the results reported by this author, different SVAR specifications can produce opposite results depending on factors such as specific economic sectors being analysed, stationary transformations of labor input measures and the number of lags employed in econometric specifications. We see Whelan's approach and ours as complementary. 
effect over labor input, only (that is, non-technology shocks cannot affect productivity in the long-run).

Gali's main results are the following:

(i) The estimated conditional correlations between labor input and productivity measures have a negative sign for technology shocks and a positive sign for non-technology shocks.

(ii) The estimated impulse-response functions display a contractionary pattern for labor input measures in response to technology shocks.

(iii) The productivity measures employed exhibit a pattern of temporary increase due to positive non-technology shocks.

These results are robust to specification issues, such as the use of different labor input measures (hours worked or employment) and detrending methods (data in first-differences or filtered through Hodrick and Prescott's method (HODRICK; PRESCOTT, 1997)). According to Galí, his results can be seen as evidence supporting sticky-price models.

Independent work by Shea (1999) and Basu, Fernald and Kimball (2006) also reached results similar to Gali's, where technology shocks lead to a contraction in input usage.

Working with RED and patent data from the NBER Manufacturing Productivity database, Shea (1999) estimates a VAR for a panel containing several U.S. manufacturing industries. His results show that although inputs may display a positive response to technology shocks initially, such a pattern is reverted in the long run. In particular, favorable technology shocks do not significantly affect productivity measures at any horizon, except for a subset of industries dominated by process innovations. Overall, technology shocks explain only a small fraction of input and productivity measures' volatilities at business cycle horizons, according to this author.

Basu, Fernald and Kimball (2006)(BFK, henceforth) construct modified Solow residuals that control for factors such as variable input utilization, imperfect competition and aggregation effects. These authors uncover a result where input usage presents a contractionary response to technology shocks, with equilibrium being restored only several years after the initial shock. According to the authors, their results are consistent with sticky-price models, which predict that, in response to a technology shock, input usage and investment fall in the short run. These authors also report the possibility that technology shocks may cause output to fall, an opposite prediction to those based on RBC models.

Christiano, Eichenbaum and Vigfusson (2003) (CEV) have questioned most of the empirical findings described above. Basically, these authors argue that labor input's dynamic response may depend on the way one models its data-generating 
process (DGP). Hence, if hours worked are modeled as an I(1) process - and it is specified in first-differences - its dynamic response to technology shocks will be invariably negative. However, if it is specified as a stationary process $(\mathrm{I}(0))$, its dynamic response will be totally reversed, with labor input displaying a positive response to technology shocks. Actually, this is a question related to problems concerning unit-root tests. CEV present compelling evidence in this sense, by using an alternative unit-root test, the KPSS test, where the null hypothesis corresponds to the hypothesis of stationarity (Kwiatkowsky et al. 1992). These authors' results cast doubt on Gali's and BFK's main findings and, at the same time, tend to favor RBC models (although CEV stress that technology shocks play a more fundamental role at low rather than at high frequencies).

In response to CEV's findings, Francis and Ramey (2005) (FR) proposed several tests which reject the first authors' findings. By employing alternative specifications where labor is modelled as an I(1) process as well as an I(0) process, FR obtain different impulse responses for hours worked: a negative response for specifications where hours enter as first-differences and a positive response for specifications where hours enter as levels. However, FR show that there is an important problem with SVAR specifications where hours enter in levels. In these specifications, the SVAR identification condition (that non-technology shocks do not have a long-run impact over productivity, by construction) is violated. If this happens, the conclusions obtained from such specifications tend to be quite misleading. Additionally, these authors perform Granger-causality tests in the same spirit as Hall (1988) and Evans (1992) in order to verify if technology and non-technology shocks derived from different SVAR estimations can be characterized as such. ${ }^{4}$ According to these authors, productivity measures which are good proxies for true technology should be unaffected by macroeconomic variables that do not reflect technological factors per se. FR's results show that only technology shocks extracted from first-differences specifications obey the Hall-Evans invariance property, a result that confirms their adequacy as proxies.

In the next section, we describe the empirical framework used in the analysis below while in the fifth section we perform empirical tests related to the debate cited above in order to verify the robustness of the main results obtained.

Using the SVAR methodology, it is possible to construct "technology" and "non-technology" components of both series employed in estimations (productivity and hours). For more details, see Galí (1999). 


\section{Empirical Framework}

We employ the standard empirical framework used in the literature. That is, we estimate a SVAR of the form:

$$
\left[\begin{array}{l}
\Delta x_{t} \\
\Delta n_{t}
\end{array}\right]=\left[\begin{array}{ll}
C^{11}(L) & C^{12}(L) \\
C^{21}(L) & C^{22}(L)
\end{array}\right]\left[\begin{array}{c}
\varepsilon_{t}^{z} \\
\varepsilon_{t}^{m}
\end{array}\right]=C(L) \varepsilon_{t}
$$

where $\mathrm{x}$ denotes (labor) productivity and $n$ denotes labor input (hours worked). The terms $\left\{\varepsilon_{z}^{t}\right\}$ and $\left\{\varepsilon_{m}^{t}\right\}$ can be seen as two orthogonal shocks, the first representing technology shocks and the second representing non-technology shocks (demand shocks, in a broader sense).

The SVAR long-run identification condition means that $C_{12}(l)=0(\mathrm{C}(\mathrm{l})$ is a lower-triangular matrix). From coefficient estimates of $\mathbf{C}(\mathrm{L})$, we are able to derive impulse response functions as well as conditional correlation coefficients, in the same way as Galí (1999) does. The conditional correlation coefficients are given by the formula:

$$
\rho\left(\Delta x_{t}, \Delta n_{t} / i\right)=\frac{\sum_{j=0}^{\infty} C_{j}^{1 i} C_{j}^{2 i}}{\sqrt{\operatorname{var}\left(\Delta x_{t} / i\right) \operatorname{var}\left(\Delta n_{t} / i\right)}}
$$

where $i={ }_{\infty} z, m$ stands for technology and non-technology components, while $\operatorname{var}\left(\Delta x_{t} / i\right)=\sum_{j=0}^{\infty}\left(C_{j}^{i j}\right)^{2}$ and $\operatorname{var}\left(\Delta n_{t} / i\right)=\sum_{j=0}^{\infty}\left(C_{j}^{2 i}\right)^{2}$ represent conditional variances of productivity and labor input measures, respectively.

\section{Variables Employed}

We use the same datasets employed by Galí, CEV and FR. Basically, these correspond to datasets containing output and labor input measures from different sources. Galí employs data from Citibase while CEV employ DRI Economics Database. FR's data come from the Bureau of Labor Statistics (BLS), National Income and Product Accounts (NIPA) and the Bureau of Economic Analysis (BEA).

We are interested in constructing labor productivity measures from the output and labor input measures we have. We do this in the same way as Galí (1999) originally did: (labor) productivity corresponds to the difference between the natural logarithms of output and labor input. Additionally, following the guidelines suggested by CEV, we use not only raw measures for labor input, but also per 
capita measures, since these are in accordance with RBC models' theoretical specifications. When performing SVAR estimations, we use the same parameters as FR do for all the datasets considered in the analysis. ${ }^{5}$

\section{Results}

As a first step in our empirical strategy, we perform several unit-root tests (Augmented Dickey-Fuller (ADF), Phillips-Perron (PP) and KPSS) over labor input measures. In performing these tests, we decided to consider four lags in each specification. Although CEV use eight lags when performing KPSS tests, they do not justify such a choice. Their test statistic (which value is .4) does not reject the null hypothesis of stationarity for labor input measures considered at a $5 \%$ level (critical value of .46), although it is rejected at a $10 \%$ level (critical value of .347). Since this evidence seems fragile, we decided to check the robustness of this result by employing an alternative number of lags in the KPSS tests reported below. Table 1 contains results for ADF and PP tests while Table 2 contains results for KPSS tests. ${ }^{6}$

Table 1 - ADF and PP tests for labor input measures

\begin{tabular}{lll}
\hline \multicolumn{1}{c}{ Variable } & ADF & PP \\
\hline Galí (1999) & & \\
\hline Hours & -2.72 & -2.43 \\
Hours per capita & $-3.36^{*}$ & -3.09 \\
\hline FR (2005) & & \\
\hline Hours & -2.4 & -2.2 \\
Hours per capita & -2.14 & -2.13 \\
\hline CEV (2003) & & -2.0 \\
\hline Hours & -2.24 & -1.93 \\
\hline Hours per capita & -1.76 & \\
\hline
\end{tabular}

Source: Authors' calculations.

Notes: (a) Sample Periods: 1947:01/1994:04 (Galís dataset); 1947:01/2003:01 (FR's dataset); 1947:01/2001:04 (CEV's dataset); (b) In the case of the ADF test, we considered specifications with a constant, a linear trend and four lags. In the case of the PP test, we considered specifications with three lags, following Newey-West's suggestion. Critical values for these tests are reported in Dickey and Fuller (1981) and Mackinnon (1991); (c) The $\left({ }^{*}\right),\left({ }^{* *}\right)$ and $\left({ }^{* * *}\right)$ symbols denote rejection of each test's null hypothesis at the $10 \%, 5 \%$ and $1 \%$ significance levels, respectively.

$5 \quad$ We run SVAR specifications employing four lags of each variable. Reported standard errors were computed through a Monte Carlo procedure with 1,000 replications and the estimated impulse response functions consider a 20-quarter horizon. We decided to adopt this parameterization in order to make results comparable across different datasets. Results reported below are robust to alternative specifications.

$6 \quad$ Results of unit-root tests are robust to differences in sample periods as well as different number of lags employed when running each test. 
Table 2 - KPSS test for labor input measures

\begin{tabular}{lllll}
\hline \multicolumn{1}{c}{ Variable } & \multicolumn{3}{c}{ Null Hypothesis } \\
\hline & $\begin{array}{c}\text { Stationarity around a } \\
\text { constant }\end{array}$ & \multicolumn{2}{c}{ Stationarity around a trend } \\
\hline LM Statistic & Lags & LM Statistic & Lags \\
\hline Galí (1999) & & & & \\
\hline Hours & $3.893^{* * *}$ & 4 & $.5762^{* * *}$ & 4 \\
Hours per capita & $2.805^{* * *}$ & 4 & .1133 & 4 \\
\hline FR (2005) & & & & 4 \\
\hline Hours & $4.3388^{* * *}$ & 4 & $.9564^{* * *}$ & 4 \\
\hline Hours per capita & $2.4465^{* * *}$ & 4 & $.9304^{* * *}$ & 4 \\
\hline CEV (2003) & & & & 4 \\
\hline Hours & $4.214^{* * *}$ & 4 & $.9502^{* * *}$ & 4 \\
Hours per capita & $2.2215^{* * *}$ & 4 & $.9025^{* * *}$ & 4 \\
\hline
\end{tabular}

Source: Authors' calculations.

Notes: (a) Sample Periods: 1947:01/1994:04 (Galís dataset); 1947:01/2003:01 (FR's dataset); 1947:01/2001:04 (CEV's dataset); (b) In the case of the KPSS test, we considered specifications with four lags. Critical values for this test are reported in Kwiatkowski et al. (1992); (c) The $\left({ }^{*}\right),(* *)$ and $(* *)$ symbols denote rejection of the test's null hypothesis at the $10 \%, 5 \%$ and $1 \%$ significance levels.

Since the tests cited above are known for displaying distortions in terms of power and size, we also report results based on the tests proposed by Elliot, Rothemberg and Stock (1996) (MADFGLS) and Ng and Perron (2001) (MPPGLS). These tests provide alternatives to conventional tests in terms of removing deterministic trends from the original series as well as providing endogenous lag-length criteria. Table 3 presents the results from such tests. 
Table 3 - MADFGLS and MPPGLS tests for labor input measures

\begin{tabular}{|c|c|c|c|c|c|}
\hline \multicolumn{6}{|c|}{ Levels } \\
\hline & $\begin{array}{c}\text { MADFGLS } \\
\{1\}\end{array}$ & $\begin{array}{c}\text { MADF }{ }^{G L S} \\
\{1, t\}\end{array}$ & $\begin{array}{c}\mathrm{MZ} \alpha^{\mathrm{GLS}} \\
\{1\}\end{array}$ & $\begin{array}{c}\mathrm{MZ} \alpha^{\mathrm{GLS}} \\
\{1, \mathrm{t}\}\end{array}$ & $\begin{array}{c}\text { Lags } \\
\{1\} ;\{1, t\}\end{array}$ \\
\hline \multicolumn{6}{|l|}{ Galí (1999) } \\
\hline Hours & 2.53 & -.79 & 1.93 & -1.74 & $1 ; 12$ \\
\hline Hours per capita & .44 & $-3.04^{* *}$ & .99 & $-22.84^{* *}$ & $12 ; 5$ \\
\hline \multicolumn{6}{|l|}{ FR (2005) } \\
\hline Hours & 1.73 & -1.4 & 1.68 & -4.17 & $1 ; 1$ \\
\hline Hours per capita & .16 & -.89 & .27 & -2.31 & $12 ; 12$ \\
\hline \multicolumn{6}{|l|}{ CEV (2003) } \\
\hline Hours & 1.81 & -1.34 & 1.93 & -3.79 & $1 ; 1$ \\
\hline Hours per capita & -.62 & -.83 & -1.22 & -2.08 & $1 ; 8$ \\
\hline \multicolumn{6}{|c|}{ First-Differences } \\
\hline & $\begin{array}{c}\text { MADFGLS } \\
\{1\}\end{array}$ & $\begin{array}{c}\text { MADFGLS } \\
\{1, \mathrm{t}\}\end{array}$ & $\begin{array}{c}\mathrm{MZ} \alpha^{\mathrm{GLS}} \\
\{1\} \\
\end{array}$ & $\begin{array}{c}\mathrm{MZ} \alpha^{\mathrm{GLS}} \\
\{1, \mathrm{t}\} \\
\end{array}$ & $\begin{array}{c}\text { Lags } \\
\{1\} ;\{1, t\}\end{array}$ \\
\hline \multicolumn{6}{|l|}{ Galí (1999) } \\
\hline Hours & $-2.22^{* *}$ & $-6.49 * * *$ & $-10.13 * *$ & $-56.72 * * *$ & $9 ; 0$ \\
\hline Hours per capita & $-2.05^{* *}$ & $-6.24^{* * *}$ & $-7.51 *$ & $-53.77 * * *$ & $9 ; 0$ \\
\hline \multicolumn{6}{|l|}{ FR (2005) } \\
\hline Hours & $-3.16 * * *$ & $-7.16^{* * *}$ & $-20.79 * * *$ & $-79.92 * * *$ & $10 ; 1$ \\
\hline Hours per capita & $-2.48 * *$ & $-7.3^{* * *}$ & $-8.88^{* *}$ & $-82.22 * * *$ & $10 ; 1$ \\
\hline \multicolumn{6}{|l|}{ CEV (2003) } \\
\hline Hours & $-2.63 * *$ & $-6.76 * * *$ & $-11.94^{* *}$ & $-74.16 * * *$ & $10 ; 1$ \\
\hline Hours per capita & $-6.87 * * *$ & $-7.21 * * *$ & $-74.21 * * *$ & $-80.76 * * *$ & $1 ; 1$ \\
\hline
\end{tabular}

Source: Authors' calculations.

Notes: (a) Critical values for this test are reported in Mackinnon (1991). For more information, see Elliot, Rothemberg and Stock (1996) and Ng and Perron (2001); (b) The number of lags chosen for each test was chosen based on the Modified Akaike Information Criterium (MAIC); (c) The $\left({ }^{*}\right),\left({ }^{* *}\right)$ and $\left({ }^{* * *}\right)$ symbols denote rejection of each test's null hypothesis at the $10 \%, 5 \%$ and $1 \%$ significance levels.

The results reported in tables 1-3 indicate that the majority of labor input measures contained in the different datasets can be characterized as non-stationary variables. The exception is the hours per capita measure of Gali's dataset, which appears to be stationary according to most test results. When running SVAR models below, we still consider specifications where labor input enters in levels, in order to check the robustness of the results obtained.

Table 4 reports results for conditional ("technology" and "non-technology") correlations estimated (SVAR specification with hours in first-differences). 
Table 4 - Labor Input-Productivity Correlations

\begin{tabular}{|c|c|c|c|}
\hline & Unconditional & \multicolumn{2}{|c|}{ Conditional (SVAR) } \\
\hline \multicolumn{4}{|l|}{ Galí } \\
\hline Hours & & Technology & Non-Technology \\
\hline First-Differences & $\begin{array}{c}-.26 * * * \\
(.08)\end{array}$ & $\begin{array}{c}-.82 * * * \\
(.12)\end{array}$ & $\begin{array}{c}.26 * * * \\
(.12)\end{array}$ \\
\hline Hours per capita & & Technology & Non-Technology \\
\hline First-Differences & $\begin{array}{c}-.24^{* * *} \\
(.08)\end{array}$ & $\begin{array}{c}-.88^{* * *} \\
(.1)\end{array}$ & $\begin{array}{l}.29 * * * \\
(.11)\end{array}$ \\
\hline \multicolumn{4}{|l|}{$\mathrm{FR}$} \\
\hline Hours & & Technology & Non-Technology \\
\hline First-Differences & $\begin{array}{l}-.04 \\
(.07)\end{array}$ & $\begin{array}{c}-.84^{* * * *} \\
(.16)\end{array}$ & $\begin{array}{c}.64 * * * \\
(.09)\end{array}$ \\
\hline Hours per capita & & Technology & Non-Technology \\
\hline First-Differences & $\begin{array}{l}-.07 \\
(.07)\end{array}$ & $\begin{array}{c}-.88^{* * *} \\
(.14)\end{array}$ & $\begin{array}{l}.6^{* * * *} \\
(.09)\end{array}$ \\
\hline \multicolumn{4}{|l|}{ CEV } \\
\hline Hours & & Technology & Non-Technology \\
\hline First-Differences & $\begin{array}{c}-.27^{* * *} \\
(.07)\end{array}$ & $\begin{array}{c}-.91 * * * \\
(.07)\end{array}$ & $\begin{array}{l}54 * * * \\
(.13)\end{array}$ \\
\hline Hours per capita & & Technology & Non-Technology \\
\hline First-Differences & $\begin{array}{c}-.29^{* * * *} \\
(.08)\end{array}$ & $\begin{array}{c}-.92 * * * \\
(.06)\end{array}$ & $\begin{array}{l}.5 * * * \\
(.11)\end{array}$ \\
\hline Mean & -.2 & -.88 & .47 \\
\hline
\end{tabular}

Source: Authors' calculations.

Notes: (a) Sample Period: 1948:02/1994:04; (b) The reported coefficients were estimated from specifications involving a constant and four lags of each variable; (c) Standard errors (in parentheses) were obtained from a Monte Carlo procedure based on 1000 draws; (d) The (*), (**) and $(* * *)$ symbols denote rejection of each test's null hypothesis at the $10 \%, 5 \%$ and $1 \%$ significance levels.

In terms of unconditional correlations, the results obtained point to a negative or null association between productivity and labor input measures. While the results based on Gali's and CEV's datasets are around -.3, results based on FR's dataset come closer to zero, with both results being in accordance with the empirical evidence available for the U.S. (see Hansen and Wright, 1992, Table 3, for instance). In terms of conditional correlations, the differences are minor. The table's last line shows the estimated coefficient's averages. Technology components average - .88 while non-technology components average .47 . The sign and magnitude of these coefficients are compatible with the interpretation contained in Gali (1999), with all of them being statistically significant at a $1 \%$ level. These results confirm Galî's original findings. According to this author, conditional correlations based on 
technology shocks should have a negative sign while the opposite should be true in the case of non-technology shocks.

In graphs 1 to 6 below we report the estimated impulse response functions for all datasets. ${ }^{7}$

Graph 1- Impulse Response Functions for Galî’s (1999) data: first-differenced hours
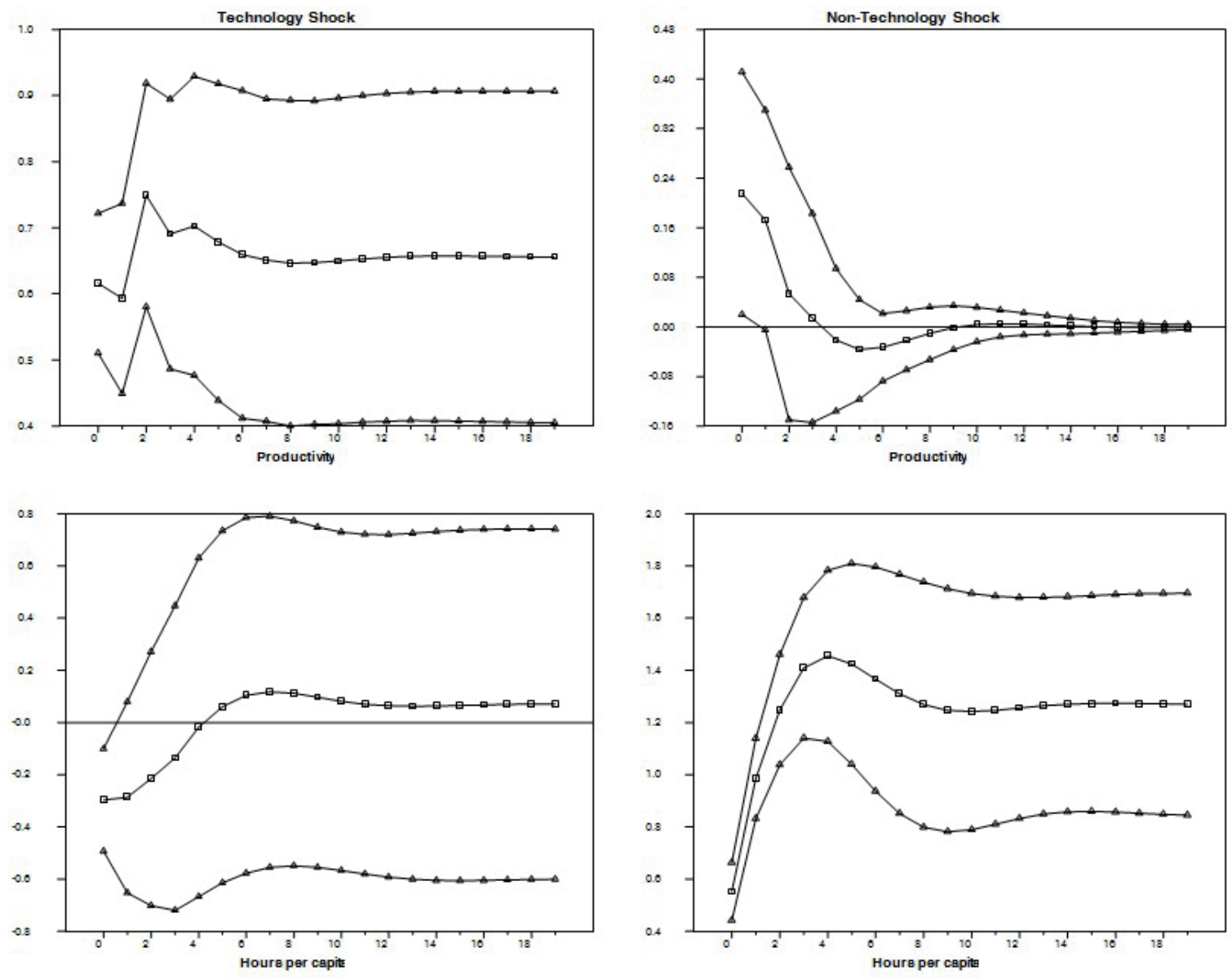

Source: Elaborated by the authors. $\begin{array}{ll}7 & \text { Due to space constraints, we decided to report impulse response functions for per capita hours, } \\ \text { only. Results remain the same when we use raw hours measures, instead. }\end{array}$ 
Graph 2 - Impulse Response Functions for Galîs (1999) data: hours in levels
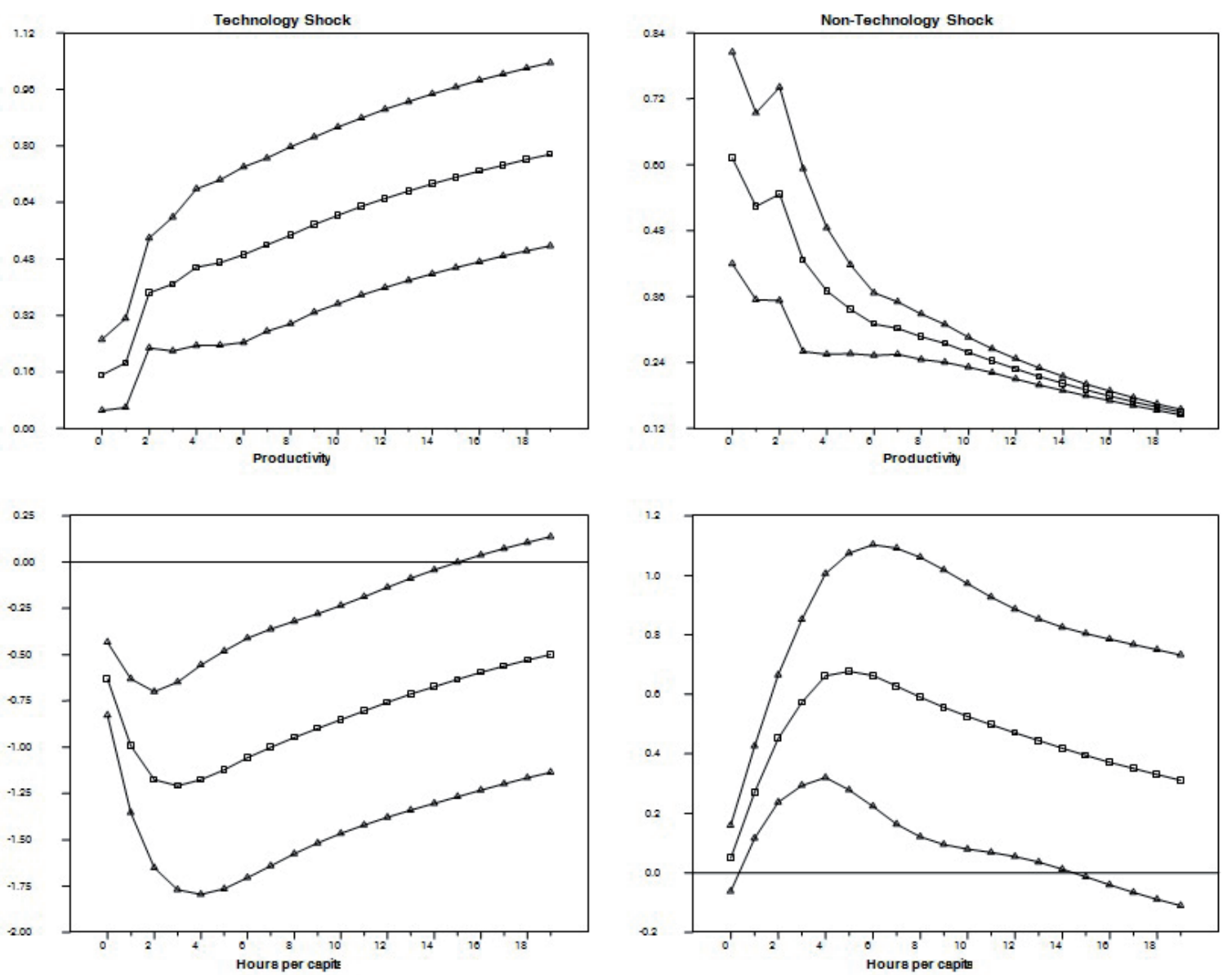

Source: Elaborated by the authors. 
Graph 3 - Impulse Response Functions for FR's (2003) data: first-differenced hours
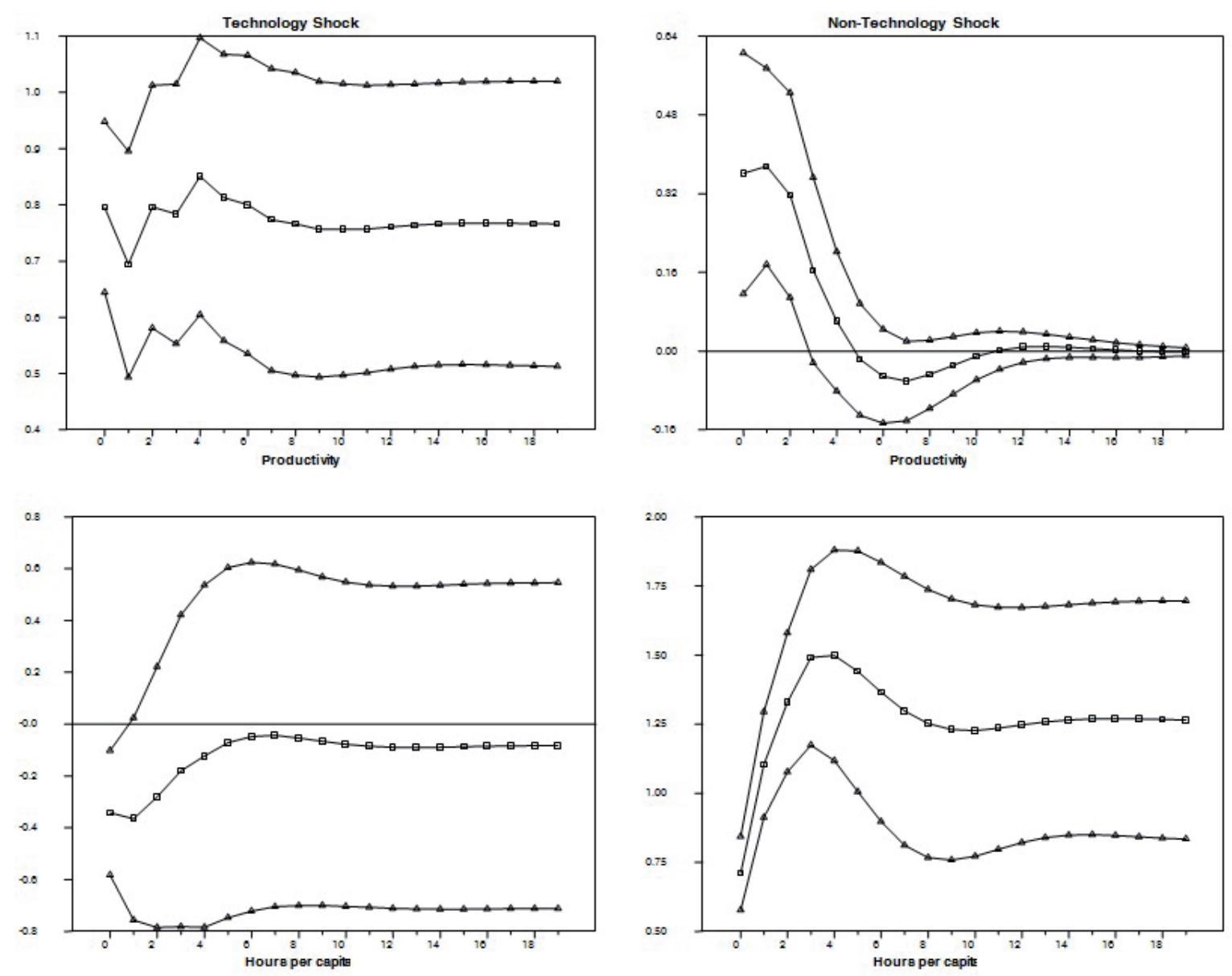

Source: Elaborated by the authors. 
Graph 4 - Impulse Response Functions for FR's (2003) data: hours in levels
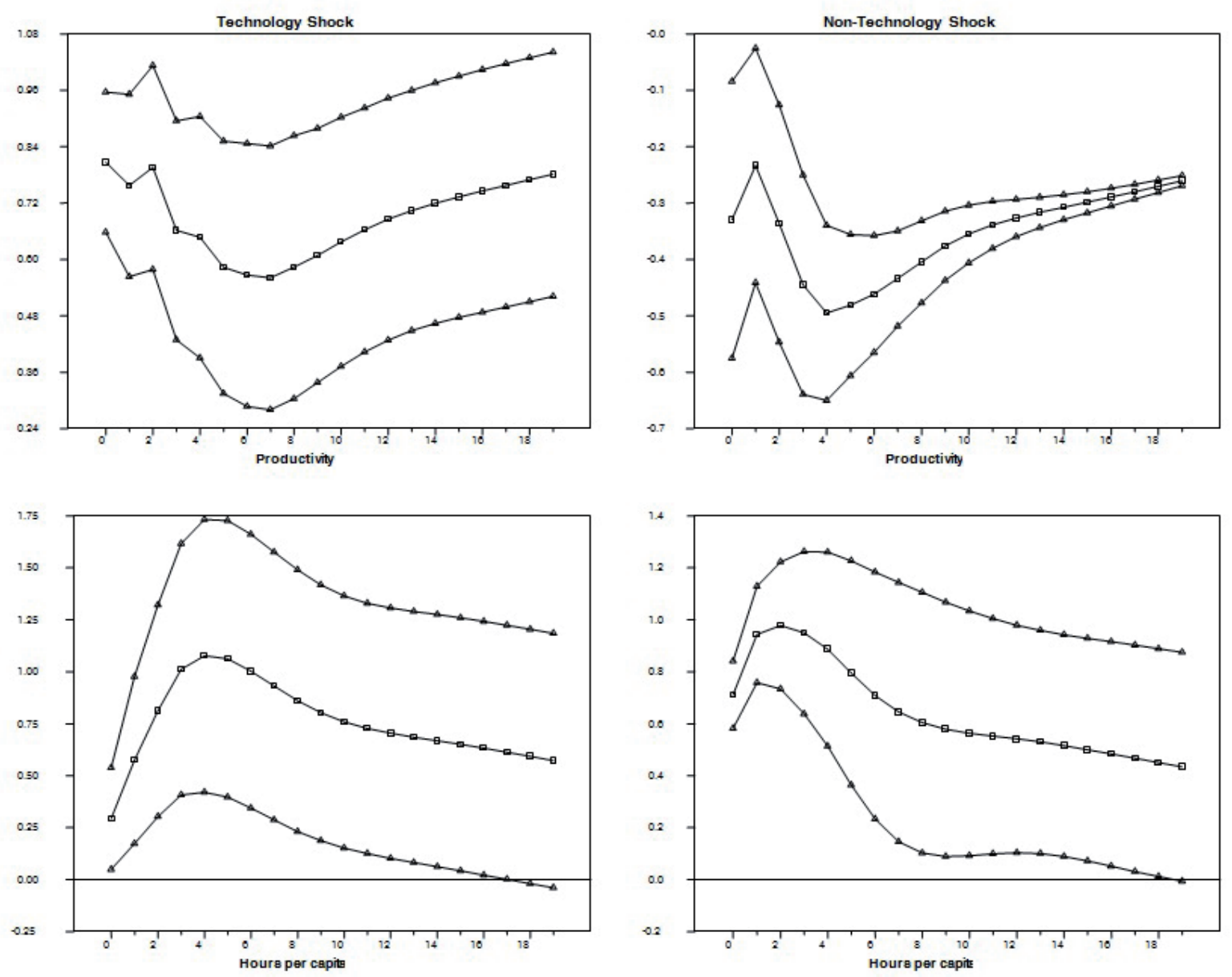

Source: Elaborated by the authors. 
Graph 5 - Impulse Response Functions for CEV's (2003) data: first-differenced hours
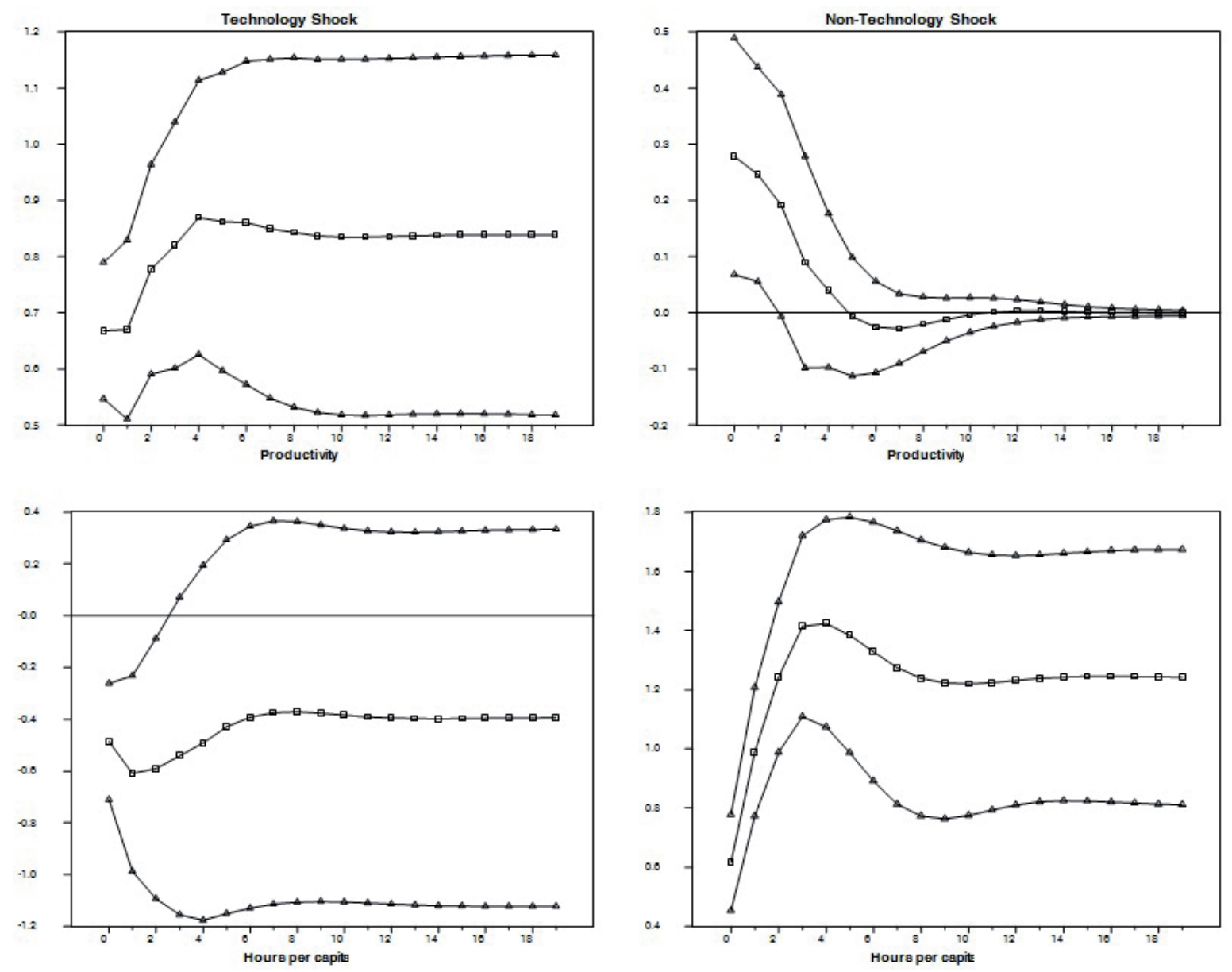

Source: Elaborated by the authors. 
Graph 6 -Impulse Response Functions for CEV's (2003) data: hours in levels
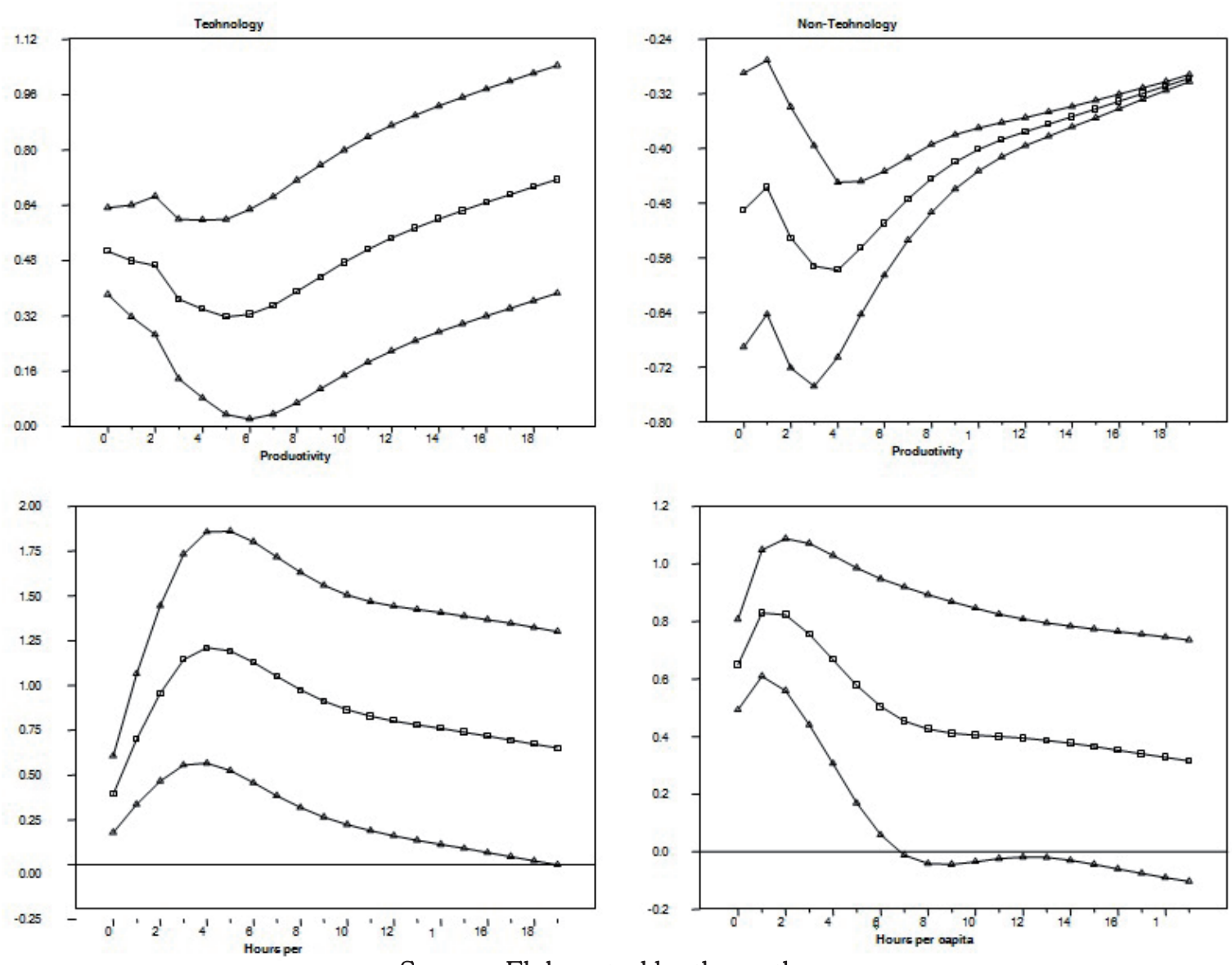

Source: Elaborated by the authors. 
In terms of estimated impulse responses, we can notice that, in the case of first-differences specifications, productivity displays a permanent positive response to technology shocks, while hours per capita display an initial negative response. Notice that, in the case of Gali's dataset, hours return to a positive level after four quarters, with the final impact of technology shocks over hours being positive. In the case of FR's and CEV's datasets, however, hours display a permanent and negative response to technology shocks. In terms of non-technology shocks, although productivity displays a positive response initially, it converges to zero after a few quarters (by construction, since this represents SVAR's identification condition). Hours per capita always display a permanent positive response to non-technology shocks, with results being consistent across all datasets. It is important to notice that, in the case of all datasets, there is a high degree of uncertainty when estimating labor input's response to technology shocks. In particular, estimated confidence intervals go through zero in the case of two or more periods after the initial shock.

In the case of levels specifications, productivity still displays a permanent positive response to technology shocks. Hours respond positively to technology shocks in the case of FR's and CEV's datasets, but they display a prolonged and negative response in the case of Gali's dataset. ${ }^{8}$ When we consider the effects of non-technology shocks, note that productivity always displays a permanent positive response to these shocks, violating the identification condition underlying estimated SVARs. This result casts doubt on the validity of specifications where labor input enters in levels. In the case of the levels specification, hours per capita also display a permanent positive response to non-technology shocks.

An additional test based on FR's insights is to perform Granger-causality tests involving technology and non-technology measures derived from the SVAR estimations previously performed. In doing so, we use the same macroeconomic variables used by FR (Ramey-Shapiro Dates, Hoover-Pérez Dates, Romer-Romer Dates and the Federal Funds Rate). These variables are used as proxies reflecting factors unrelated to technology. ${ }^{9}$ According to this test's logic, technology components extracted from SVAR estimations should not be affected by the macroeconomic variables cited above. Results of these tests are contained in tables 5 and 6 below.

\footnotetext{
$8 \quad$ In particular, in the case of Galís original dataset, we obtain a result where output also displays a negative response to technology shocks in the case of levels specifications (not shown). This result can be seen as counterintuitive, since it implies that technology shocks have a contractionary effect on output, a conclusion contrary to the theoretical predictions of first-generation $\mathrm{RBC}$ models. On the other hand, this result confirms BFK's insight that output may present a contractionary response to technology shocks in sticky-price models. The graphs containing this result are available from the authors upon request.

$9 \quad$ For more information about the construction of these variables, see Francis and Ramey (2005).
} 
Table 5 - Granger-Causality Tests: First-Differences Specification

\begin{tabular}{lcccc}
\hline Shocks & $\begin{array}{c}\text { Ramey-Shapiro } \\
\text { Dates }\end{array}$ & $\begin{array}{c}\text { Hoover-Perez } \\
\text { Dates }\end{array}$ & $\begin{array}{c}\text { Romer-Romer } \\
\text { Dates }\end{array}$ & $\begin{array}{c}\text { Federal Funds } \\
\text { Rate }\end{array}$ \\
\hline Galí & & & & \\
\hline Technology & .166 & .589 & .322 & .129 \\
Non-Technology & $.004^{* * *}$ & $.000^{* * *}$ & $.005^{* * *}$ & $.000^{* * *}$ \\
\hline FR & & & & \\
\hline Technology & .201 & .905 & .446 & .355 \\
Non-Technology & .535 & $.000^{* * *}$ & $.016^{* *}$ & $.000^{* * *}$ \\
\hline CEV & & & & .753 \\
\hline Technology & .12 & .956 & .442 & $.000^{* * *}$ \\
Non-Technology & .135 & $.000^{* * *}$ & $.009^{* * *}$ & \\
\hline
\end{tabular}

Source: Authors' calculations.

Notes: (a) Sample Period: 1948:02/1994:04; (b) Granger-causality tests were performed with specifications involving the regresion of SVAR's components on a constant, a current and four lagged values of the dummy variables employed (except for the Federal Funds Rate, where we did not include current values). The values reported in the table represent probabilities associated with the test's null hypothesis that all estimated coefficients are jointly zero; (c) The $\left({ }^{*}\right),\left({ }^{* *}\right)$ and $\left({ }^{* * *}\right)$ symbols denote rejection of each test's null hypothesis at the 10\%, $5 \%$ and $1 \%$ significance levels.

Table 6 - Granger-Causality Tests: Levels Specification

\begin{tabular}{|c|c|c|c|c|}
\hline \multirow[t]{2}{*}{ Shocks } & \multicolumn{4}{|c|}{ Macroeconomic Variables } \\
\hline & $\begin{array}{c}\text { Ramey-Shapiro } \\
\text { Dates }\end{array}$ & $\begin{array}{c}\text { Hoover-Perez } \\
\text { Dates }\end{array}$ & $\begin{array}{c}\text { Romer-Romer } \\
\text { Dates }\end{array}$ & $\begin{array}{c}\text { Federal Funds } \\
\text { Rate }\end{array}$ \\
\hline \multicolumn{5}{|l|}{ Galí } \\
\hline Technology & .254 & $.075^{*}$ & .358 & $.074^{*}$ \\
\hline Non-Technology & $.042^{* *}$ & $.093 *$ & $.094^{*}$ & $.000 * * *$ \\
\hline \multicolumn{5}{|l|}{$\mathrm{FR}$} \\
\hline Technology & $.06^{*}$ & $.046^{* *}$ & .555 & $.006 * * *$ \\
\hline Non-Technology & .423 & .37 & .103 & $.000 * * *$ \\
\hline \multicolumn{5}{|l|}{ CEV } \\
\hline Technology & $032 * *$ & $.046 * *$ & .609 & $.001 * * *$ \\
\hline Non-Technology & .272 & .315 & .184 & .683 \\
\hline
\end{tabular}

Source: Authors' calculations.

Notes: See Table 2. 
The results contained in the tables above show that technology components extracted from first-differences specifications are not Granger-caused by any of the measures considered by FR. At the same time, non-technology components are Granger-caused by most measures. On the other hand, technology components extracted from levels specifications are Granger-caused by more than one of the measures used to capture variables not related to technological factors. In particular, these technology components are all Granger-caused by movements in the Federal Funds Rate.

The results reported here point to first-difference specifications as more appropriate than levels specifications, at the same time that they represent evidence favorable to Gali's and FR's main findings.

\section{Conclusions and Future Research}

In this note, we checked the robustness of some of the empirical findings contained in Gali's, CEV's and FR's studies. Our results confirm Galî's and FR's findings, at the same time that they go against CEV's.

The results reported here show the importance of specifying hours worked as growth rates instead of levels. In particular, specifications where labor input is modeled in levels display counterintuitive results: SVAR's identification condition is always violated and, in the case of one dataset (Gali's), output presents a contractionary dynamic response to technology shocks. Also, the SVAR's technology components derived from levels specifications violate the Hall-Evans' invariance property, which casts doubt on its validity as good proxies for productivity shocks.

More work is still needed to demonstrate which theoretical approach (flexible or rigid prices settings) should be preferred when studying the effects of technology shocks in the short run. In accordance with Gali's and FR's approach, our results favor theoretical models where nominal rigidities play an important role in explaining aggregate fluctuations. Future research efforts may show which additional elements are necessary to explain the macroeconomic effects of technology shocks in the short run.

\section{References}

BASU, S.; FERNALD, J. G.; KIMBALL, M. Are technology improvements contractionary? American Economic Review, v. 96, n. 5, p. 1418-1448, Dec. 2006.

BLANCHARD, O.; QUAH, D. T. The dynamic effects of aggregate demand and supply disturbances. American Economic Review, v. 79, n. 4, p. 655-673, Sept. 1989.

CHRISTIANO, L. J.; EICHENBAUM, M.; VIGFUSSON, R. What happens after a technology shock? Northwestern University, mimeo., May 2003. 
COLLARD, F.; DELLAS, H. Supply shocks and employment in an open economy. Economics Letters, v. 82, p. 231-237, 2004.

DICKEY, D. A.; FULLER, W. A. Likelihood ratio statistics for autoregressive time series with a unit root. Econometrica, v. 49, n. 4, p. 1057-1073, 1981.

ELLIOT, G.; ROTHEMBERG, T. J.; STOCK, J. H. Efficient tests for an autoregressive unit root. Econometrica, v. 64, p. 813-836, 1996.

EVANS, C. I. Productivity shocks and real business cycles. Journal of Monetary Economics, v. 29, n. 2, p. 191-208, Apr. 1992.

FRANCIS, N.; RAMEY, V. A. Is the technology-driven real business cycle hypothesis dead? Shocks and aggregate fluctuations revisited. Journal of Monetary Economics, v. 52, n. 8, p. 1379-1399, Nov. 2005.

GALÍ, J. Technology, employment and the business cycle: do technology shocks explain aggregate fluctuations? American Economic Review, v. 89, n. 1, p. 249-271, Mar. 1999.

GALI, J.; RABANAL, P. Technology shocks and aggregate fluctuations: how well does the RBC model fit postwar U.S. data? NBER Macroeconomics Annual, 2004.

HALL, R. E. The relation between price and marginal cost in U.S. industry. Journal of Political Economy, v. 96, n. 5, p. 921-947, 1988.

HANSEN, G. D.; WRIGHT, R. The labor market in real business cycle theory. Federal Reserve Bank of Minneapolis Quarterly Review, p. 2-12, Spring 1992.

HODRICK, R.; PRESCOTT, E. C. Post-War U.S. business cycles: a descriptive empirical investigation. Journal of Money, Credit and Banking, v.29, n.1, p.1-16, 1997.

KWIATKOWSKI, D. et al. Testing the null hypothesis of stationarity against the alternative of unit root. Journal of Econometrics, v. 54, n. 1, p. 159-178, 1992.

MACKINNON, J. G. Critical values for cointegration tests. In: ENGLE, R. F.; GRANGER, C. W. J. (Ed.). Long-run economic relationships: readings in cointegration. Oxford University, 1991.

NG, S.; PERRON, P. Lag length selection and the construction of unit root tests with good size and power. Econometrica, v. 69, v. 6, p. 1519-1554, 2001.

SHEA, J. What do technology shocks do? NBER Macroeconomics Annual 1998, v. 13, p. 275$310,1999$.

WHELAN, K. Technology shocks and hours worked: checking for robust conclusions. Journal of Macroeconomics, v. 31, n. 2, p. 231-239, Jun. 2009.

Recebido em: 08/07/2011.

Aceito em: 05/06/2012. 